\title{
Activity and emission inventory of open waste burning at the household level in developing countries: a case study of Semarang City
}

\author{
Bimastyaji Surya Ramadan ${ }^{1,2}$ (1) $\cdot$ Indriyani $\operatorname{Rachman}^{1,3} \cdot$ Toru Matsumoto $^{1}$
}

Received: 16 September 2021 / Accepted: 26 January 2022 / Published online: 19 February 2022

(c) Springer Japan KK, part of Springer Nature 2022

\begin{abstract}
In this study, total burned household waste and the potential emissions released from waste burning in Semarang City, Indonesia, were estimated. Waste piles were monitored using the transect walk survey method in 16 sub-districts of Semarang City. Carbon monoxide $(\mathrm{CO})$, carbon dioxide $\left(\mathrm{CO}_{2}\right)$, hydrocarbon $(\mathrm{HC})$, nitrous oxide $\left(\mathrm{NO}_{\mathrm{x}}\right)$, and total particulate matter (TPM) were directly analyzed through a simulation of waste combustion. The potential emissions from other pollutants were predicted by multiplying the weight of the burned waste by the emission factors available in the literature. The estimated waste burned in Semarang City in 2020-2021 was $58.8 \mathrm{Gg} / \mathrm{year}$, or approximately $9.70 \%$ of the total waste generated in Semarang City. This estimation exceeds local government estimates of 2020 by two-fold. Peri-urban areas (both inner and outer) were identified as the most significant contributors to waste burning. Further, garden waste was the most burned waste (73.61\%), followed by plastic waste (17.45\%). Other wastes, including paper, leather, textile, rubber, and food, were also burned. Overall, a decrease in the activity of waste burning is an important step for reducing the potential of air pollution and climate change.
\end{abstract}

Keywords Developing countries · Estimated emission · Open burning $\cdot$ Peri-urban areas $\cdot$ Waste mismanagement

\section{Introduction}

Proper waste management is becoming a primary concern for many municipalities in developing countries. Inadequate waste management systems lead to traditional open burning, burying, and random disposal [1], which are carried out at relatively higher levels in rural areas where waste collection services are unavailable [2]. In most rural areas of developing countries, open burning is most commonly practiced, instead of random dumping or disposal, recycling,

Bimastyaji Surya Ramadan

b0dac401@eng.kitakyu-u.ac.jp

1 Department of Life and Environment Engineering, Faculty of Environmental Engineering, The University of Kitakyushu, Kitakyushu 808-0135, Japan

2 Department of Environmental Engineering, Faculty of Engineering, Universitas Diponegoro, Semarang 50275, Indonesia

3 Department of Natural Science Education, School of Postgraduate Studies, Universitas Pakuan, Bogor 16143, Indonesia and burying practice, by the local population [3]. In fact, this pattern was found in the rural part of Huejutla City, Mexico, where at least $22.4 \%$ of the waste is burned [4]. In the rural areas of Thailand [5], Southwest China [3], and Iran [6], open burning is the dominant waste management practice, accounting for more than $30.0 \%$ of all practices. However, open burning of waste is also performed in urban areas in many developing countries as it is an easier option for eliminating waste. For instance, in the urban area of Kampala City, at least $13 \%$ of the population burns their waste [7]. Reducing the number of dumping and burning practices is part of the international strategic objectives that must be achieved to meet the sustainable development goals (SDGs) by 2030; thus, reducing these practices is an important task.

Open-burning municipal solid waste (MSW) processes are inefficient owing to limited oxygen supply and poorly controlled temperature. This incomplete combustion results in toxin emission, such as particulate matter (PM), carbon monoxide (CO), and other gases, into the atmosphere without any air pollution control [8]. Occasionally, the open burning of MSW contains considerable plastic waste, which is the most significant source of dioxins and other 
halogenated compounds [9]. Pansuk and his team reported that plastic waste is the second-highest waste in rural Thailand (31.7\%). Some primary toxic aerosols, such as smoke and carbonaceous compounds, are released, thereby polluting the environment and harming human health [5]. Open burning may thus significantly contribute to air pollution compared to emissions from the transportation and industrial sectors [10]. An emission inventory is needed to identify suitable methods to control pollution and better understand the negative effects of open waste burning. However, an open burning activity data inventory, which may divert from the evaluation system and enable the implementation of laws and policies related to reducing open burning practices, is lacking $[9,11]$.

Most of the mass estimation for open burning is derived from questionnaire-based survey and literature-based assumptions, which either results in an overestimation or underestimation of the open burning incident itself. Therefore, some researchers have employed another approach to derive the best results for burned MSW mass estimation. A team of researchers led by Nagpure, Raj, and Ramaswami used transect walks to determine the number of active burning piles, and the social and infrastructural factors affecting open burning, as well as estimate the number of illegal dumping of MSW and its physical characteristics in India [9, 12-14]. Das et al. employed a different approach by combining household survey and the transect walk method to validate the $P_{\text {frac }}$ value of the IPCC calculation method (fraction of people burning waste in a household) [15]. In a recent study, Krecl et al. used a transect walk survey principle to identify fire spots in specific areas [8]. Overall, more field estimation studies regarding open waste burning are required to assemble an appropriate emission inventory for a specific country. In this study, the amount of unmanaged waste in Semarang City, Indonesia, was determined. Due to the lack of high-level (tier) data inventory, especially in open waste burning, waste pile composition and characteristic analyses were conducted in this study. The information presented in this study will be essential for evaluating policy and law interventions, and other potential future research benefits related to open waste burning.

\section{Methods}

This study sought to estimate burning activities, incidents, and emissions in the selected sub-district area of Semarang City. The transect walk survey methods were modified from previous methods employed in India, Mexico, and Nepal [9, $15,16]$. The laboratory test used to determine waste composition was carried out according to Nagpure et al., while the test to determine the emission from MSW was carried out with the method of Park and his team [17, 18].

\section{Study area profile}

Semarang City, the capital city of Central Java Province, is considered a metropolitan city as it was one of the top six cities with the highest gross domestic product (GDP) in Indonesia in 2019. The GDP per capita of Semarang City reached 105.59 million rupiahs and is constantly increasing by approximately 7\% each year [19]. Semarang City is also considered an urban coastal city as it is located south of the Java Sea. Semarang City consists of 16 districts divided into 177 sub-districts, with Wonolopo as the largest sub-district ( area $=1,459.53 \mathrm{ha}$ ), and Sukorejo as the smallest sub-district ( $\operatorname{area}=15 \mathrm{ha}$ ). Based on the following background, Semarang City might generate more waste than other cities. Waste generation is reported to increase by $2-4 \%$ each year and Semarang City is estimated to produce 606,728 tons of waste annually. This waste is dominated by organic waste $(53.86 \%)$, followed by plastic $(21.52 \%)$, paper $(10.97 \%)$, metals $(8.72 \%)$, and other products $(4.93 \%)$ [20]. Most of the waste in the city is generated from households (76\%), market (14\%), industry (4\%), and others (6\%) [21]. It is estimated that $4.54 \%$ of the waste is recycled through informal actors in Semarang City. Plastic is becoming the most recovered and recycled waste (53-56\%) compared to paper, metals, glass, and others [19, 21]. According to the Semarang City Government estimation, $77.75 \%$ of municipal waste is processed at the landfill site, $17.65 \%$ of waste is processed at the source in material recovery facilities available in some districts, and $4.60 \%$ of waste is burned, buried, and disposed directly into the environment. The amount of waste collected in 2019 was estimated to be 390,915 ton/year. The researchers used K-means cluster methods to obtain four different clusters with similar characteristics. Each cluster was identified and named using the definition of urban area classification, such as rural, outer peri-urban, inner peri-urban, and urban, by Hanna Karg and her team [22]. Figure 1 describes the position of each selected subdistrict (transect area) on the Semarang City Map.

\section{Transect walk survey method}

The transect walk survey methods follow those employed in a previous successful study by Das et al. and Nagpure et al. $[9,15]$. The transect walk routes were determined randomly for each sub-district belonging to the four clusters mentioned above. Each route was approximately $10 \mathrm{~km}$ long and could either be a neighborhood loop or a straight line. The survey was conducted in the rainy season from mid-January to mid-February 2021 and during the semi-lockdown policy for COVID-19 in Semarang City. 


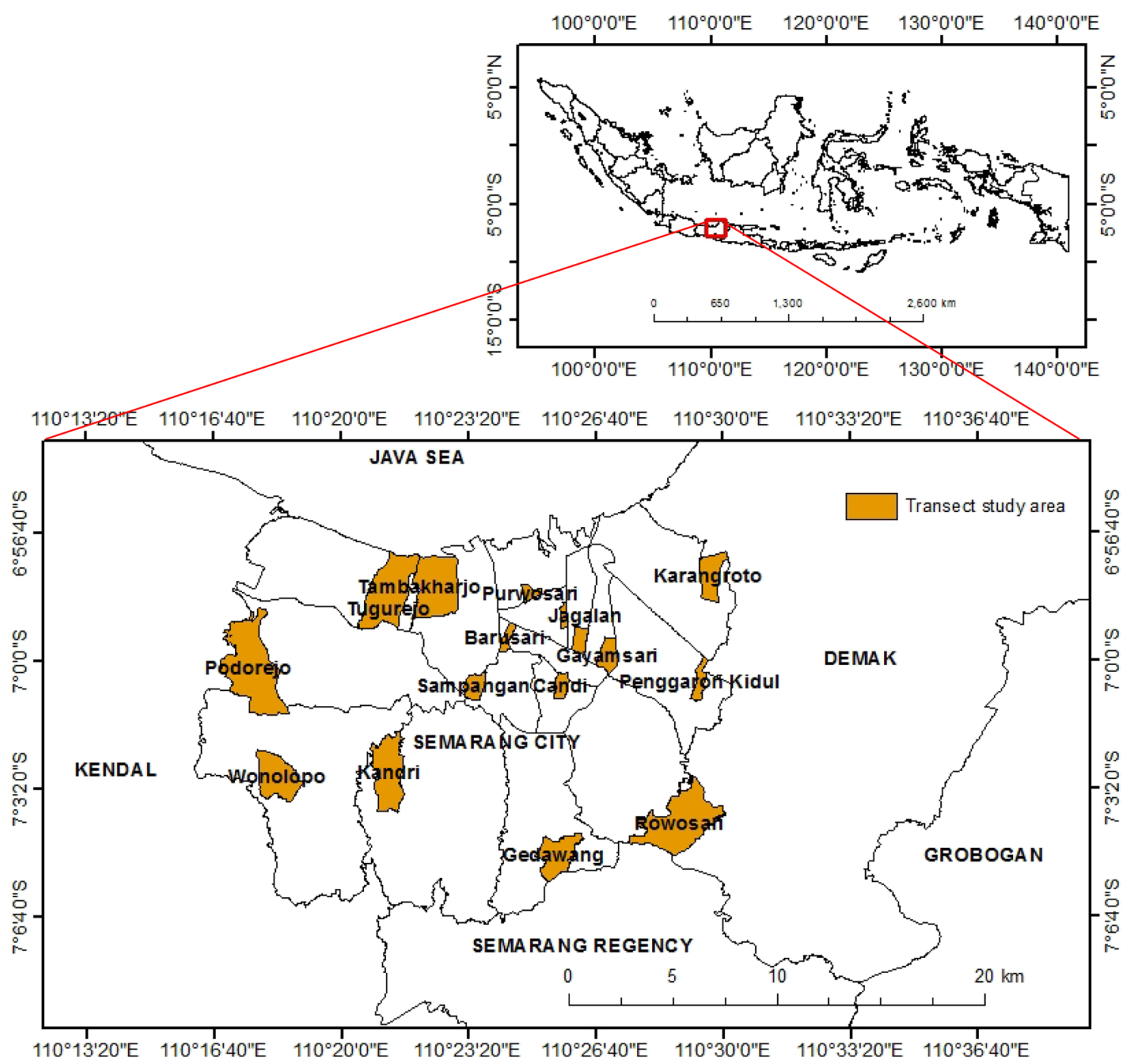

Fig. 1 Semarang City maps and transect study areas

Preliminary surveys were also conducted to ensure the performance of open burning at the household and landfill sites. The surveyors were well prepared and equipped with a mask, gloves, handheld global positioning system (GPS), and a camera. The surveyors asked the local people about their burning practice frequency once during the transect. This field-based experiment was carried out in the morning and afternoon on two different days (fourtime surveys). The total number of piles was the sum of the piles found from the first to the fourth survey. During the transect walk survey, the surveyor recorded the waste pile coordinates, dimensions (estimated width, length, and height using measure tape and stick), distance from road/place perpendicular to the road, photos, and conditions (currently burn, burned, half-burned, or not burned). Waste piles that were not burned were categorized as potentially unmanaged waste, buried, fed to animals, or other potential waste practices. Landfill site was not considered as burning sources, as there were no reported waste burning incidents.

\section{Calculation method of transect walk results}

The transect results (in volume) were converted into a weight basis after the specific density of the waste piles was determined. Each route's estimated pile weight was divided by the transect area to determine the pile density (see Eqs. $(1,2,3))$

$\sum M_{a}=\sum V_{a} \times \rho_{a}$

$\operatorname{Tr} A_{a}=\operatorname{Tr} L_{a} \times S S$ 
$M_{b}=\frac{\sum M_{a}}{\operatorname{Tr} A_{a} \times 1000}$

where $M_{a}$ and $V_{a}$ are the weight $(\mathrm{kg})$ and volume $\left(\mathrm{m}^{3}\right)$ of the waste pile in each district, respectively; $\rho_{a}$ is the compaction density of the piles $\left(\mathrm{kg} / \mathrm{m}^{3}\right) ; \operatorname{Tr} A_{a}$ and $\operatorname{Tr} L_{a}$ are the transect area $\left(\mathrm{m}^{2}\right)$ and transect line (m) of the specific surveyed area (in each sub-district), respectively; SS is the maximum sightseeing (m); 1000 is the conversion factor from $\mathrm{kg}$ to ton; and $M_{b}$ is the estimated weight density of the pile in each sub-district $\left(\operatorname{ton} / \mathrm{km}^{2}\right)$. Pile density of each cluster $\left(M_{c}\right)$ was determined by dividing the total of estimated weight density of the surveyed areas $\left(M_{b}\right)$ by 4 which is representing the number of sub-districts in each cluster (see Eq. (4)).

$M_{c}=\frac{\sum M_{b}}{4}$

The total unmanaged waste in Semarang City $\left(M_{w}\right)$ was calculated from the cluster's pile density $\left(M_{\mathrm{cn}}\right)$ with the total area of each cluster-covered area $\left(A_{n}\right)$. As it is shown in the Eq. (5), $n$ refers to the cluster number. The total weight of the burned waste in Semarang City was estimated by multiplying the total unmanaged waste $\left(M_{w}\right)$ with the fraction of waste burning incidents $\left(f_{\mathrm{wb}}\right)$ which was obtained from the waste pile condition in the transect walk survey (see Eq. (6)).

$M_{w}=\left(M_{c 1} \times A_{1}\right)+\left(M_{c 2} \times A_{2}\right)+\left(M_{c 3} \times A_{3}\right)+\left(M_{c 4} \times A_{4}\right)$

$M_{\mathrm{wb}}=M_{w} \times f_{\mathrm{wb}}$

The average pile density of each cluster $\left(M_{\mathrm{cn}}\right)$ was also multiplied by the population density $\left(P_{d}\right)$ and fraction of waste burning incidents $\left(f_{\mathrm{wb}}\right)$ to determine the coarse estimation of burned waste per capita in each cluster $\left(M_{\mathrm{pc}}\right)$ (see Eqs. (7) and (8)).

$P_{d}=\frac{P}{A}$

$M_{\mathrm{pc}}=P_{d} \times M_{c} \times f_{\mathrm{wb}}$

Semarang City waste generation was estimated by assuming $3.74 \mathrm{l} /$ person/day of waste per capita, $245 \mathrm{~g} / \mathrm{l}$ of waste density [23], and 1,814,110 persons of the Semarang City population in 2019. Information regarding the collected waste sent to the landfill was obtained from the Environmental Services Government of Semarang City.

\section{Laboratory test}

Of the 16 routes determined, unburned waste was randomly collected (approximately $3-5 \mathrm{~kg}$ ) from each route to assess its characteristics, composition, raw weight, and specific density. The unburned waste was divided into 11 categories: food waste, branches and twigs, paper and cardboard, plastic, metal, textile, rubber, glass, leaves, hazardous waste, and other waste. Thereafter, the 16 waste compositions were grouped and averaged as a defined cluster; these compositions were essential for determining waste composition for the combustion tests. The design of the combustion test and the burning procedure followed that of Park et al., as shown in Fig. 2 [18]. Approximately $2-4 \mathrm{~kg}$ of backyard waste was found to be burned. The initial suction blower discharge was approximately $8 \mathrm{~m}^{3} / \mathrm{min}$, and the average flow rate of the dust collection was $5.5 \mathrm{~m}^{3} / \mathrm{min}$. The waste was burned to completion. The average time taken to obtain wholly burned waste was approximately $25-30 \mathrm{~min}$. The temperature of the burning chamber was approximately $400-500{ }^{\circ} \mathrm{C}$. Fly ash was taken from the cyclone output, and bottom ash was taken from the bottom of the combustion chamber. The fly ash was weighed to determine the TPM emission factors. The oxygen concentration and flue gas, including $\mathrm{HC}, \mathrm{CO}_{2}$, $\mathrm{CO}$, and $\mathrm{NO}_{\mathrm{x}}$, were measured using a QROTech (QRO-402) gas analyzer. The burning test was repeated three times to improve the data accuracy. The flue gas concentration was counted 12 times in $24 \mathrm{~min}$. The emission factor of the TPM was calculated using the Eq. (9) proposed by Park et al. [18]:

$\mathrm{EF}=\frac{s \times\left(\frac{Q}{Q_{p}}\right)}{M}$

where $s$ is the mass of the fly ash collected in the cyclone, $\left(\frac{Q}{Q_{p}}\right)$ is the fraction of flow rate in the dust collection divided by the flue gas flow rate, and $M$ is the total burned mass of the waste. The burning efficiency can be calculated by dividing the mass burned to completion by the raw/initial weight of the waste. Some emission parameters were estimated using the references' emission factors. The total emissions of municipal waste burning were calculated using the Eq. (10) proposed by Das et al. [15]:

$\mathrm{Em}=M_{i} \times \mathrm{EF}_{i}$

where $M_{i}$ is the total burned mass of waste, $\mathrm{EF}_{i}$ is the emission factor of the particular parameters, and $\mathrm{Em}$ is the total emission of the pollutant.

\section{Results}

\section{Transect walk results}

During the transect walk, visual observation was conducted to determine the composition of the waste burned (see Table 1). In Semarang City, backyard waste consisting of branches, twigs, and leaves is the main waste burned, 
Fig. 2 Laboratory test incinerator
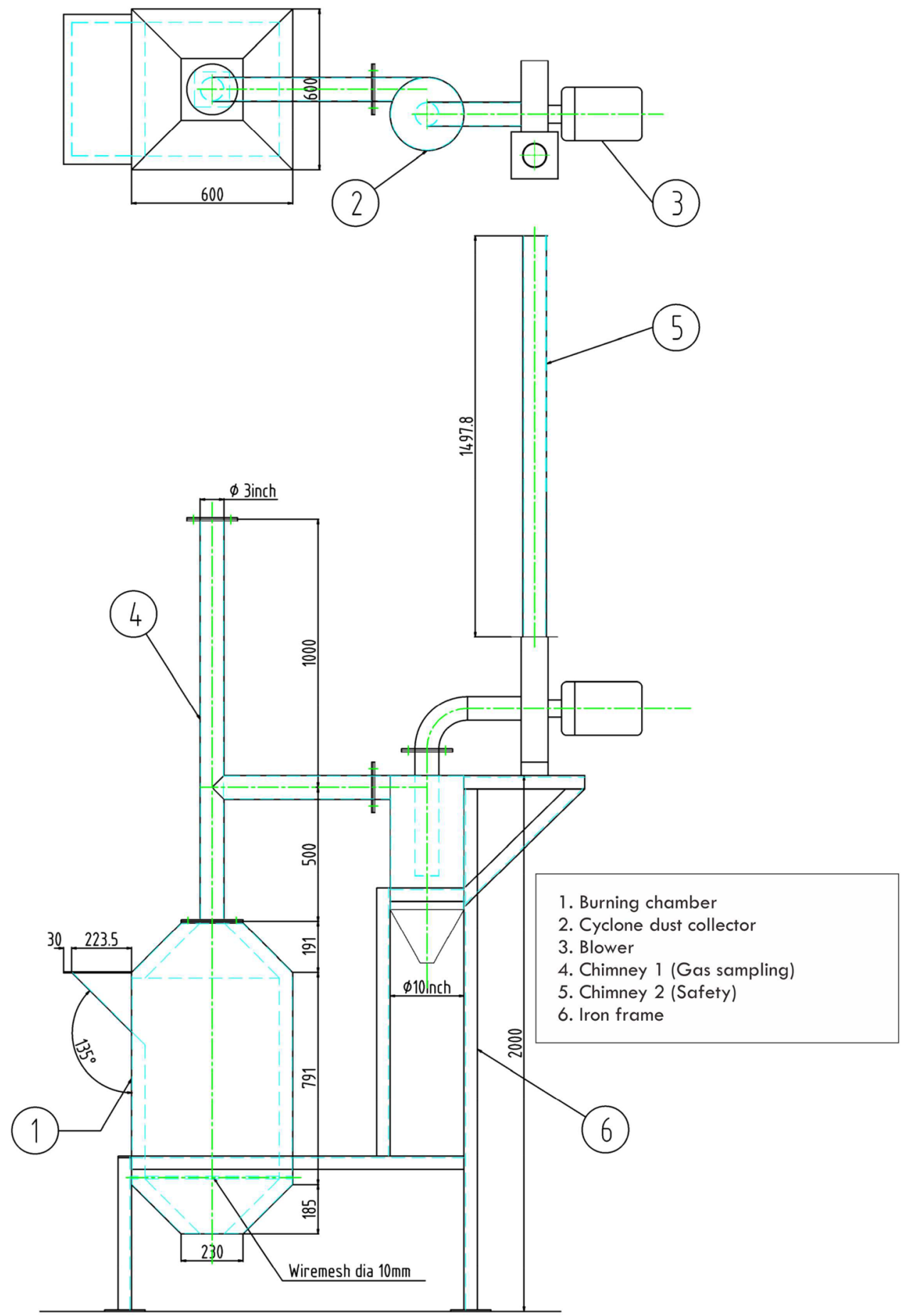

accounting for $73.61 \%$ of the total burned waste. Plastic waste was always the second-largest contributor to waste burned after backyard waste in all areas. The average compaction density was $90 \pm 48 \mathrm{~kg} / \mathrm{m}^{3}$, and the average moisture content was $43.13 \pm 19.50 \%$. Although all sub-districts were in a similar city, a significant variation in the geographical boundary, socioeconomic activities, and lifestyle, was found, which led to different densities and compositions. Therefore, the burned waste was assumed to have a relatively high combustible fraction value (0.72).

A total of 171 piles were identified during the transect walk survey at the household level. As shown in Table 2, the highest number of piles was found in the Karangroto subdistrict (inner peri-urban area), while the lowest pile number and pile density were found in the Jagalan and Barusari subdistricts (urban area), respectively. Notably, the total piles 
Table 1 Waste piles composition (\%)

\begin{tabular}{lccccc}
\hline Waste Composition & Cluster 1 (Rural) & $\begin{array}{l}\text { Cluster 2 } \\
\text { (Outer periur- } \\
\text { ban) }\end{array}$ & $\begin{array}{l}\text { Cluster 3 } \\
\text { (Inner periur- } \\
\text { ban) }\end{array}$ & $\begin{array}{l}\text { Cluster } \\
\text { 4(Urban } \\
\text { Core) }\end{array}$ & Semarang City \\
\hline Food waste & 0.57 & 0.08 & 0.00 & 0.00 & 0.16 \\
Branch and twig & 66.08 & 73.95 & 8.37 & 32.99 & 45.35 \\
Paper and cardboard & 9.46 & 2.98 & 2.22 & 2.67 & 4.33 \\
Plastic & 4.33 & 7.50 & 42.07 & 15.91 & 17.45 \\
Metal & 0.00 & 0.60 & 0.10 & 0.30 & 0.25 \\
Textile & 0.35 & 8.67 & 0.84 & 0.00 & 2.46 \\
Rubber & 0.00 & 0.00 & 2.12 & 1.07 & 0.80 \\
Leaves & 19.20 & 5.03 & 42.24 & 46.57 & 28.26 \\
Hazardous waste & 0.00 & 0.00 & 0.03 & 0.49 & 0.13 \\
Others & 0.00 & 1.18 & 2.01 & 0.00 & 0.80 \\
\hline
\end{tabular}

in each cluster showed a different pattern, with the rural area displaying the highest number of piles. The average pile density shows a sequential order from the highest to the lowest pile density from rural to urban areas. Interestingly, the inner or outer peri-urban area, also called the transition area, had the highest number of open burning, thereby differing from the results of previous research [4]. Only $19.33 \%$ of the total waste piles in the transect areas were not burned during visual inspection. Therefore, the highest burning intensity was found in the inner peri-urban area, which aligns with a previous finding that peri-urban areas contribute the most to open burning in Semarang City.

In the per-capita context, rural areas were found to have the highest burning incidents compared to other areas (see Table 3). Each person can be estimated to burn $0.539 \mathrm{~kg}$ of waste per day; however, a lower number was found in urban areas. Therefore, this estimated result aligns with the collection points available in each cluster. For instance, a lower waste collection efficiency in the rural cluster has been reported, enabling a higher possibility of open burning practice. In the peri-urban area, the number of burning incidents per capita was lower than that in rural areas, indicating that an appropriate number of waste collection units and services is provided in the area. Therefore, a high level of waste collection services, population density, and environmental awareness in urban areas may reduce the possibility of burning incidents.

\section{Scale-up of transect walk results}

After the amount of waste burned in each cluster was estimated, the average waste burned density in the cluster was multiplied by the total area of each cluster in Semarang City. The outer peri-urban area was the largest contributor to open burning, with $50.82 \%$ of the total waste burned in Semarang City. The lowest estimate for waste burning was found in the urban core, with only $2.74 \%$ of the total waste burned or $0.27 \%$ of the total waste generated in Semarang City. As shown in Table 4, the estimation number may align with that of other previous studies, such as studies in Nepal and India, where the city core was found to only contribute a maximum of $2 \%$ of the total waste generated in the city [15, 17]. The total estimation of waste burned in Semarang City was 161.17 tons/day or $9.70 \%$ of the total waste generated in Semarang City. This estimation is 2.5-fold lower than the estimation predicted by Reyna-Bensusan, where the total open burning in the city was $22.4 \%$ [4]. Therefore, the periurban area is predicted to contribute significantly to open burning emissions in the city.

\section{Emission of municipal waste burning}

The emission of uncontrolled waste burning varies significantly according to the composition of the waste [18]. As shown in Table 5 , different waste compositions produce a variety of emissions. For instance, when the concentration of plastic waste was high, the average concentration of $\mathrm{CO}$ was relatively higher than that in other burning incidents. In addition, a higher paper/cardboard composition in burning incidents results in higher NOx. During the 24 min of open waste burning, a significant amount of $\mathrm{CO}$ and $\mathrm{CO}_{2}$ is produced at the beginning of the burning activity. The $\mathrm{CO}$ and $\mathrm{CO}_{2}$ emissions reach their peak after $8 \mathrm{~min}$ of burning, and NO and hydrocarbons increase after $10 \mathrm{~min}$ of uncontrolled burning. Therefore, the burning efficiency was found to differ among the four samples. The highest burning efficiency $(91.81 \%)$ was found in Cluster 1, where the highest backyard waste was found; this was followed by cluster 4 , which had a lower proportion of non-combustible waste. Clusters 2 and 3 were found to have the lowest burning efficiency, with only $57-59 \%$ of waste being burned owing to the presence of many incombustible wastes in the waste composition. The concentration of all pollutants decreased significantly when the fuel was exhausted. Accordingly, the findings of this 


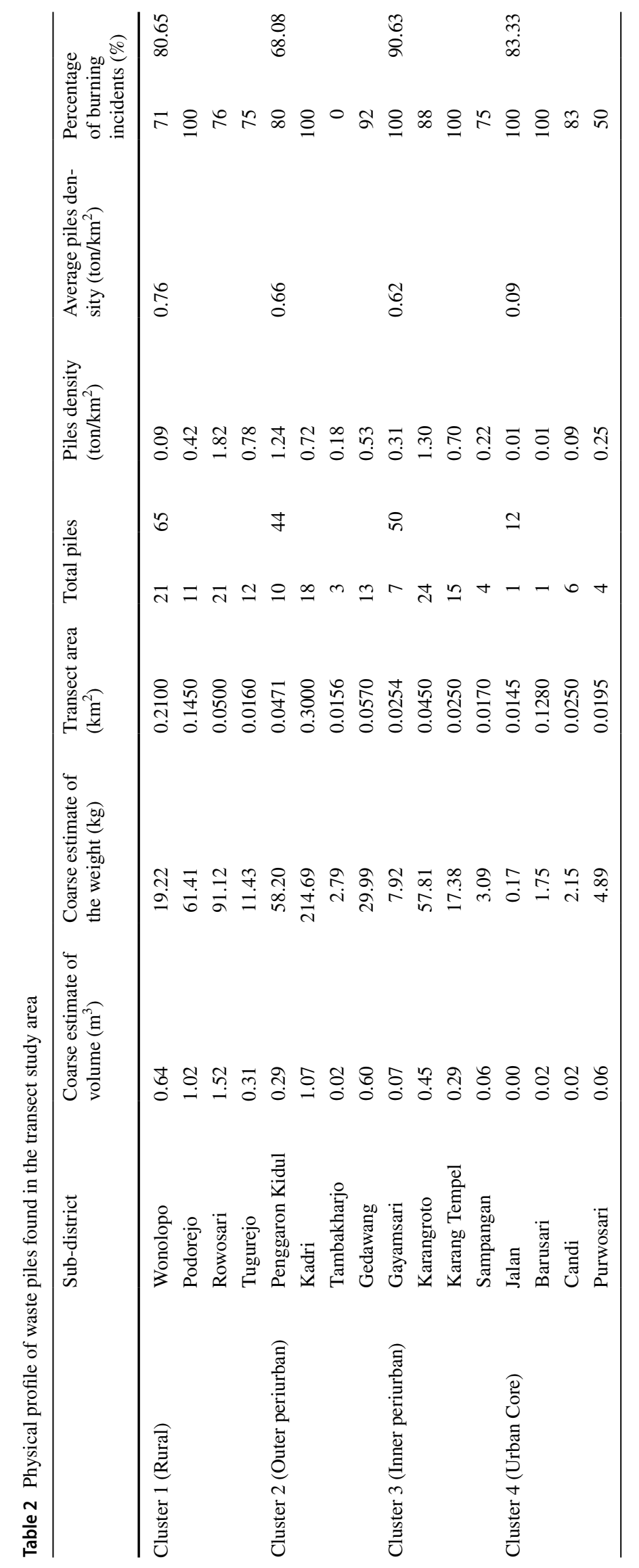


Table 3 Estimation of burning intensity per capita in each sub-district and cluster

\begin{tabular}{|c|c|c|c|c|c|c|c|}
\hline \multirow[t]{2}{*}{ Cluster } & \multirow[t]{2}{*}{ Sub-district } & \multirow[t]{2}{*}{ Population (capita) } & \multirow[t]{2}{*}{ Areas $\left(\mathrm{km}^{2}\right)$} & \multicolumn{4}{|c|}{$\begin{array}{l}\text { Coarse estimation of burning intensity (kg waste/capita } \\
\text { day) }\end{array}$} \\
\hline & & & & $\begin{array}{l}\text { Non- } \\
\text { burning } \\
\text { incidents }\end{array}$ & Average & Burning incidents & Average \\
\hline \multirow[t]{4}{*}{ Cluster 1 (Rural) } & Wonolopo & 9864 & 14.60 & 0.026 & 0.129 & 0.109 & 0.539 \\
\hline & Podorejo & 9376 & 9.72 & 0.085 & & 0.354 & \\
\hline & Rowosari & 12,381 & 8.70 & 0.248 & & 1.033 & \\
\hline & Tugurejo & 7550 & 8.63 & 0.158 & & 0.659 & \\
\hline \multirow[t]{4}{*}{ Cluster 2 (Outer periurban) } & Penggaron Kidul & 7202 & 2.53 & 0.138 & 0.083 & 0.295 & 0.176 \\
\hline & Kandri & 4827 & 2.45 & 0.116 & & 0.248 & \\
\hline & Tambakharjo & 3297 & 1.67 & 0.029 & & 0.062 & \\
\hline & Gedawang & 9598 & 2.70 & 0.047 & & 0.101 & \\
\hline \multirow[t]{4}{*}{ Cluster 3 (Inner periurban) } & Gayamsari & 12,385 & 0.93 & 0.002 & 0.009 & 0.021 & 0.088 \\
\hline & Karangroto & 14,015 & 2.06 & 0.018 & & 0.171 & \\
\hline & Karang Tempel & 3942 & 0.92 & 0.015 & & 0.147 & \\
\hline & Sampangan & 10,623 & 0.97 & 0.002 & & 0.015 & \\
\hline \multirow[t]{4}{*}{ Cluster 4 (Urban Core) } & Jagalan & 5811 & 0.27 & 0.000 & 0.001 & 0.000 & 0.004 \\
\hline & Barusari & 6151 & 0.40 & 0.000 & & 0.001 & \\
\hline & Candi & 11,595 & 0.59 & 0.001 & & 0.004 & \\
\hline & Purwosari & 8898 & 0.48 & 0.002 & & 0.011 & \\
\hline
\end{tabular}

Table 4 Comparative estimation of domestic waste burning intensity with other countries

\begin{tabular}{|c|c|c|c|c|c|c|}
\hline Countries & Location-cluster & Method of burning estimation & Population & $\begin{array}{l}\text { Waste burning } \\
\text { intensity }(\mathrm{Gg} / \\
\text { year) }\end{array}$ & $\begin{array}{l}\text { Fraction of open burning } \\
\text { with total waste generation } \\
(\%)\end{array}$ & References \\
\hline Indonesia & Semarang City-Urban & $\begin{array}{l}\text { Transect walk and field } \\
\text { survey }\end{array}$ & $1,653,524$ & 58.8 & 9.70 & This study \\
\hline Nepal & Kathmandu Valley-Urban & $\begin{array}{l}\text { Transect walk and field } \\
\text { survey }\end{array}$ & $1,751,114$ & 7.4 & 3.00 & {$[15]$} \\
\hline Mexico & $\begin{array}{l}\text { Huejutla Municipality- } \\
\text { Urban, Periurban, Rural }\end{array}$ & $\begin{array}{l}\text { Waste management survey } \\
\text { and laboratory study }\end{array}$ & 122,905 & 8.04 & 22.40 & {$[4,16]$} \\
\hline India & Delhi City-Urban & $\begin{array}{l}\text { Transect walk and field } \\
\text { survey }\end{array}$ & $16,700,000$ & 89.8 & 3.00 & [9] \\
\hline
\end{tabular}

Table 5 Concentration of $\mathrm{CO}_{2}, \mathrm{CO}, \mathrm{HC}$, and $\mathrm{NO}_{\mathrm{x}}$ emission during uncontrolled burning

\begin{tabular}{|c|c|c|c|c|c|c|c|c|c|c|c|c|c|}
\hline \multirow[t]{3}{*}{ Cluster } & \multirow{3}{*}{$\begin{array}{l}\text { Waste burned } \\
\text { composition } \\
\text { ratio* }\end{array}$} & \multicolumn{12}{|c|}{ Parameter $(\mathrm{g} / \mathrm{kg})$} \\
\hline & & \multicolumn{3}{|l|}{$\mathrm{CO}$} & \multicolumn{3}{|l|}{$\mathrm{CO}_{2}$} & \multicolumn{3}{|l|}{$\mathrm{HC}$} & \multicolumn{3}{|l|}{ NOx } \\
\hline & & Min & Ave & $\operatorname{Max}$ & Min & Ave & Max & Min & Ave & $\operatorname{Max}$ & Min & Ave & Max \\
\hline Cluster 1 (Rural) & 85: 4: $10: 1$ & 0.10 & 0.38 & 1.30 & 1.00 & 10.00 & 23.00 & 0.09 & 0.14 & 0.22 & 52.00 & 96.33 & 147.00 \\
\hline Cluster 2 (Outer periurban) & 79: $8: 3: 10$ & 0.10 & 0.34 & 1.80 & 4.00 & 11.08 & 38.00 & 0.08 & 0.11 & 0.21 & 45.10 & 76.23 & 123.40 \\
\hline Cluster 3 (Inner periurban) & 51: $42: 2: 5$ & 0.10 & 0.54 & 1.80 & 3.00 & 13.33 & 38.00 & 0.09 & 0.12 & 0.21 & 69.80 & 84.88 & 116.70 \\
\hline Cluster 4 (Urban Core) & 80: $16: 2: 2$ & 0.10 & 0.38 & 1.30 & 3.00 & 8.58 & 17.00 & 0.09 & 0.14 & 0.22 & 67.50 & 81.13 & 118.10 \\
\hline
\end{tabular}

*Backyard waste: plastic waste: paper: other waste 
test indicate that pollutants are emitted significantly during the burning of waste, ultimately harming the environment (see Suppl. Figure 6). It was also estimated that $0.48 \mathrm{~g} / \mathrm{kg}$ or 28.37 ton/year of TPM is emitted from waste burning in Semarang City. This TPM concentration is three-fold lower than the previous research [18]. Therefore, the results obtained may be higher depending on the characteristics of the waste burned and the burning conditions [24]. The emissions from the burned waste in Semarang City were lower than the global estimation. For instance, open burning emitted $2.470 \mathrm{Gg} /$ year of $\mathrm{CO}$ or 30 -fold lower emission than that estimated in Ibadan City, Nigeria [25]. In addition, another researcher estimated that the $\mathrm{PM}_{2.5}$ emission in Semarang City was 1.5-fold higher than that in the Delhi municipalities [26]. Therefore, it is estimated that the emissions from Semarang City are higher than those reported in other studies that used the same transect walk methods [15]. These differences among studies may be due to the dynamic situation of each city.

\section{Discussion}

In the present study, rural and peri-urban areas contribute significantly to the mismanagement of solid waste in Semarang City. When the findings of this study were scaled up to the city level, they appeared to slightly oppose the findings of Bensusan et al., who found that rural areas contribute the highest to waste burning events in Mexico. The peri-urban area has more complex and dynamic socioeconomic properties, where waste composition depends on the urbanization rate [27]. Open burning events in the peri-urban area of Semarang City were higher because of the deep-rooted habits of people in the transition area. The waste collection service frequency may also be reduced in this area, where some people keep their burning practices acceptable and familiar. The practice of burning becomes more convenient as it can easily remove waste when an appropriate waste collection unit is not available [4]. According to Warunasinghe and Yapa, most people in the peri-urban area have higher environmental awareness levels and willingness to engage in proper waste management in their area than people residing in other areas. However, the waste management system offered by the government is unsatisfactory, resulting in residents engaging in more convenient practices, such as waste burning. Therefore, their high expectations of proper waste management should be supported and addressed [28].

According to Nagpure et al., burned waste in the winter is higher than in the summer. This condition was found because people need heat from burning activities [9]. In twoseason-countries, especially in Semarang City, the ambient temperature does not fluctuate drastically each year. It means that the need for heat may not become the priority reason behind waste burning practices [5]. Moreover, there is a possibility of higher waste burning incidents in the dry season or non-lockdown situations since the people tend to have higher activities than in the rainy season or semi-lockdown situations. However, future studies should also confirm this situation to present better waste burning inventory.

Some strategies need to be developed to reduce the number of open burning emissions in Semarang City. First, waste collection services should be improved to cover all waste generated in Semarang City. Inadequate and irregular waste collection services encourage people to burn their waste directly [14]. Therefore, a policy may be necessary, especially in urban and inner peri-urban areas where waste collection services are still available. Proper waste recycling should be endorsed in the outer peri-urban and rural areas because a higher service area may limit the collection of household waste [29]. Recycling activities could include composting [30] and community-based inorganic waste recycling [20]. The informal sector should also be included in the waste management system of Semarang City as it is the highest contributor to waste recycling in many cities in developing countries. Therefore, the uniqueness of the transition areas could be supported by informal actors without government intervention [27].

\section{Conclusions}

According to the findings of this study, approximately 161.17 tons/day of municipal waste is burned in Semarang City, ultimately accounting for $9.70 \%$ of the total waste generated in the city. The outer peri-urban area cluster had the highest contribution to open burning, representing $50.82 \%$ of the total open burning incidents. Further, branch, twig, and leaves were identified as the most numerous burned components, followed by plastic, which pose significant risks to human health. Interestingly, the inner peri-urban and urban areas were found to have more plastic waste for burning, despite having a significantly lower number of piles than the outer peri-urban area. Based on coarse estimation per capita, the highest burning incidents per capita were found in the rural areas of Semarang City, followed by the outer peri-urban, inner peri-urban, and urban areas. Approximately $80.67 \%$ of the piles were burned while $19.33 \%$ were unburned. The unburned pile can be assumed to be buried, dumped, or disposed directly into the environment. This finding aligns with that of previous research where rural areas were found to have more per capita waste burning incidents than urban areas. In addition, the number of mismanaged wastes were three-fold higher than the local government estimates. Future studies should explore the social and economic factors that could contribute to the reduction of unmanaged waste practices in Semarang City, as well as 
determine whether the mismanaged waste in this transition area is higher than that in rural and urban areas.

Supplementary Information The online version contains supplementary material available at https://doi.org/10.1007/s10163-022-01371-3.

Acknowledgements The authors would like to thank to Muhammad Fillah Qoyyimul Haq, Afan Sulton Ashari, and Arifa Sofia Putri for helping the field survey and Editage (www.editage.com) for English language editing.

\section{References}

1. Velis CA, Cook E (2021) Mismanagement of plastic waste through open burning with emphasis on the global south: a systematic review of risks to occupational and public health. Environ Sci Technol 55(11):7186-7207. https://doi.org/10.1021/acs.est. 0c08536

2. Remigios MV (2013) Open burning of municipal solid waste in Senga surburb in the City of Gweru: a salient environmental threat. Environ Sci 3(1): 105-112

3. Han Z, Liu D, Lei Y, Wu J, Li S (2015) Characteristics and management of domestic waste in the rural area of Southwest China. Waste Manag Res 33(1):39-47. https://doi.org/10.1177/07342 42X14558668

4. Reyna-Bensusan N, Wilson DC, Smith SR (2018) Uncontrolled burning of solid waste by households in Mexico is a significant contributor to climate change in the country. Environ Res 163:280-288. https://doi.org/10.1016/j.envres.2018.01.042

5. Pansuk J, Junpen A, Garivait S (2018) Assessment of air pollution from household solid waste open burning in Thailand. Sustainability. https://doi.org/10.3390/su10072553

6. Vahidi H, Nematollahi H, Padash A, Sadeghi B, RiyaziNejad M (2017) Comparison of rural solid waste management in two central provinces of Iran. Environ Energy Econ Res 1:195-206. https://doi.org/10.22097/eeer.2017.47246

7. Kulabako RN, Nalubega M, Wozei E, Thunvik R (2010) Environmental health practices, constraints and possible interventions in peri-urban settlements in developing countries-a review of Kampala. Uganda 20(4):231-257. https://doi.org/10.1080/09603 120903545745

8. Krecl P, de Lima CH, Dal Bosco TC, Targino AC, Hashimoto EM, Okawa GY (2021) Open waste burning causes fast and sharp changes in particulate concentrations in peripheral neighborhoods. Sci Total Environ 765:142736. https://doi.org/10.1016/j.scitotenv. 2020.142736

9. Nagpure AS, Ramaswami A, Russell A (2015) Characterizing the spatial and temporal patterns of open burning of municipal solid waste (MSW) in Indian Cities. Environ Sci Technol 49(21):12911-12912. https://doi.org/10.1021/acs.est.5b03243

10. Wiedinmyer C, Yokelson RJ, Gullett BK (2014) Global emissions of trace gases, particulate matter, and hazardous air pollutants from open burning of domestic waste. Environ Sci Technol 48(16):9523-9530. https://doi.org/10.1021/es502250z

11. Permadi DA, Kim Oanh NT (2013) Assessment of biomass open burning emissions in Indonesia and potential climate forcing impact. Atmos Environ 78:250-258. https://doi.org/10.1016/j. atmosenv.2012.10.016

12. Nagpure AS (2018) Assessment of quantity and composition of illegal dumped municipal solid waste (MSW) in Delhi. Resour Conserv Recycle 141:54-60. https://doi.org/10.1016/j.resconrec. 2018.10.012
13. Lal RM, Nagpure AS, Luo L, Tripathi SN, Ramaswami A, Bergin MH, Russel AG (2016) Municipal solid waste and dung cake burning: discoloring the Taj Mahal and human health impacts in Agra. Environ Res Lett. https://doi.org/10.1088/1748-9326/11/10/ 104009

14. Ramaswami A, Baidwan NK, Nagpure AS (2016) Exploring social and infrastructural factors affecting open burning of municipal solid waste (MSW) in Indian cities: a comparative case study of three neighborhoods of Delhi. Waste Manag Res 34(11):1164 1172. https://doi.org/10.1177/0734242X16659924

15. Das B, Bhave PV, Sapkota A, Byanju RM (2018) Estimating emissions from open burning of municipal solid waste in municipalities of Nepal. Waste Manag 79:481-490. https://doi.org/10.1016/j. wasman.2018.08.013

16. Reyna-Bensusan N, Wilson DC, Davy PM, Fuller GW, Fowler GD, Smith SR (2019) Experimental measurements of black carbon emission factors to estimate the global impact of uncontrolled burning of waste. Atmos Environ 213:629-639. https://doi.org/10. 1016/j.atmosenv.2019.06.047

17. Nagpure AS, Ramaswami AA, Russell AG (2015) Characterizing the spatial and temporal patterns of open burning of municipal solid waste (MSW) in Indian Cities characterizing the spatial and temporal patterns of open burning of municipal solid waste. Environ Sci Technol 49(21):12911-12912. https://doi.org/10.1021/acs. est.5b03243

18. Park YK, Kim W, Jo YM (2013) Release of harmful air pollutants from open burning of domestic municipal solid wastes in a metropolitan area of Korea. Aerosol Air Qual Res 13(4):1365-1372. https://doi.org/10.4209/aaqr.2012.10.0272

19. Syafrudin BMA, Yuliastuti N, Ramadan BS (2021) Assessment of greenhouse gases emission from integrated solid waste management in Semarang City, Central Java. Indonesia Evergreen 8(1):23-35. https://doi.org/10.5109/4372257

20. Hadiwidodo M, Samadikun BP, Arinasandi D (2019) Study of waste bank's condition in Semarang City. E3S Web Conf 10:4-7. https://doi.org/10.1051/e3sconf/201912507010

21 Pertiwi A, Kiky SMPP, Wiwik B, Ratna P, Budi PS, Arya R (2018) Preliminary study on plastic waste handling in Semarang City-Indonesia: estimated generation and existing management. E3S Web Conf. https://doi.org/10.1051/e3sconf/20187307008

22. Karg H, Hologa R, Schlesinger J, Drescher A, Kranjac-berisavljevic $G$, Glaser R (2019) Classifying and mapping periurban areas of rapidly a multi-method approach applied to Tamale. Ghana Land 8(3):40. https://doi.org/10.3390/land8030040

23. Budihardjo MA, Wahyuningrum IFS (2018) Recovery practice of unsorted solid waste: from landfill towards economic benefits in Semarang, Indonesia. MATEC Web Conf 159:4. https://doi.org/ 10.1051/matecconf/201815901029

24. Akagi SK, Yokelson RJ, Wiedinmyer C, Alvarado MJ, Reid JS, Karl T, Crounse JD, Wennberg PO (2011) Emission factors for open and domestic biomass burning for use in atmospheric models. Atmos Chem Phys 11(9):4039-4072. https://doi.org/10.5194/ ACP-11-4039-2011

25. Okedere OB, Olalekan AP, Fakinle BS, Eliminate FB, Odunlami OA, Shonibare JA (2019) Urban air pollution from the open burning of municipal solid waste. Environ Qual Manag. https://doi.org/ $10.1002 /$ tqem. 21633

26. Guttikunda SK, Color G (2013) A GIS-based emissions inventory at $1 \mathrm{~km} \times 1 \mathrm{~km}$ spatial resolution for air pollution analysis in Delhi, India. Atmos Environ 67:101-111. https://doi.org/10. 1016/j.atmosenv.2012.10.040

27. Pan L, Lin T, Xiao L, Zhao Y, Cui S (2010) Household waste management for a peri-urban area based on analysing greenhouse gas emissions for Jimei District, Xiamen, China. Int J Sustain Dev World Ecol 17(4):342-349. https://doi.org/10.1080/13504 509.2010.492654 
28. Warunasinghe WAAI, Yapa PI (2015) A survey on household solid waste management (SWM) with special reference to a periurban area (Kottawa) in Colombo. Procedia Food Sci 6:257-260. https://doi.org/10.1016/j.profoo.2016.02.038

29. Orhorhoro EK, Ebunilo PO, Sadjere GE (2017) Determination and quantification of household solid waste generation for planning suitable sustainable waste management in Nigeria. Int J Emerg Eng Res Technol 5(8):1-9. https://doi.org/10.1016/j.profoo.2016. 02.038

30. Abadi B, Mahdavian S, Fattahi F (2021) The waste management of fruit and vegetable in wholesale markets: Intention and behavior analysis using path analysis. J Clean Prod 279:123802. https://doi.org/10.1016/j.jclepro.2020.123802

Publisher's Note Springer Nature remains neutral with regard to jurisdictional claims in published maps and institutional affiliations. 